\title{
CISG: The Relation among Cure, Fundamental Breach, and Avoidance
}

\author{
Bashar H. Malkawi*
}

\begin{abstract}
The CISG has become a uniform law which governs the sale of goods. Fundamental breach and avoidance under the CISG is one of the most difficult areas of the Convention. The CISG has left many aspects of this subject unresolved firmly and this endangers the position of the CISG as a successful platform for harmonization. The article seeks to establish the relationship between fundamental breach, cure and avoidance as provided for under the CISG. The article commences by a general overview of the instrument/convention in introductory section and goes deeper to elucidate the various methods that are used when construing the vocabulary of the various articles and other relevant provisions under the CISG. The literature review of the article gives a critical analysis of the scholarly opinion on the relevant provisions that illuminates fundamental breach, cure and avoidance. The various court decisions are also given an evaluation to give a lucid position of how the different jurisdictions have treated the articles of the CISG. The article further gives a detailed consideration of the various scholarly materials that provide a theoretical underpinning of the relevant provisions. The articles' historical development is analyzed and various cases reviewed under methodology. The article ends with a set of conclusions and recommendations. The article recommends for the necessity cure being given precedence over the right of avoidance in the circumstances where the contravention of the agreement is fundamental.
\end{abstract}

DOI: $10.7176 /$ JLPG/93-03

Publication date: January $31^{\text {st }} 2020$

\section{Objective of the Article}

This article shall seek to establish the current trends associated with international trade in agreements that relate to tangible trade and chattels. In the exploration of the emerging trends, the problems and challenges that face the current activities in international commerce are determined. Employment of technology in effecting cross border transactions and its impact on the traditional documentation in contracts shall be discussed in detail as well. This article shall seek to determine whether modern technology has completely revolutionized documentation in terms of the law and principles of contracts is concerned.

This part shall delve into the theoretical framework multinational commercial contracts. Importance shall be accorded to A. 23, 48 as well as article 49 of the CISG. Therefore, the article shall rely on secondary sources such as books, scholarly articles and journals to discuss the history and development of international laws governing international contracts pertinent to multinational trade as well as the motive behind the formation of these laws. Afterwards, the article shall seek to analyze the effect of these laws on the world states through case law and scholarly commentary. In the same breath, the applicability or rather the acceptance of the convention is of key importance.

Lastly, we shall discuss the role science and technology plays in international trade. What are the laws regulating use of technology in running international sale of goods transactions. The role and control of trade websites such as eBay, Alibaba are discussed albeit briefly in this article. This article provides a comprehensive conclusion and recommendations as to the best business practices and technology that could be enacted to streamline trade of goods across international boundaries.

\section{Interpretation of the CISG}

The wide acceptance of this convention may be attributed to inter alia, a wide range of techniques used in its drafting. ${ }^{1}$ These techniques include but are not limited to usage of neutral unambiguous language in the wording of the convention, promotion of general goodwill in international trade, by recognizing the importance of general principles of interpretation as well as underlining the significance of binding usages and international trade practice. $^{2}$

Drafters of the convention eschewed incorporation of any country's legal tradition in the convention. In so doing, the principles of the convention do not rely on any country's legal tradition or even case laws in its application. Therefore, the drafters sought to maximize the scope of the convention in the maximum number of states in the world. There are different rules employed in the reading of the convention, both provided for in the

\footnotetext{
* Professor Bashar H. Malkawi holds LLM in International Trade Law from University of Arizona and SJD from American University, Washington College of Law.

${ }^{1}$ See Pilar Perales Viscasillas, Interpretation and gap-filling under the CISG: contrast and convergence with the Unidroit Principles, 22 Uniform Law Review 4, 8-10 (2017).

${ }^{2}$ See article 9 of the CISG.
} 
CISG itself, in principles of law as well as scholarly articles. The main principles of interpretation include The UNIDROIT Principles as well as The Principles of European Contract Law (PECL).

Interpretation of CISG should have in regard to its international character. This provision under A.7 of the CISG seeks to discourage the construction of the convention using principles of any legal culture apart from international principles that govern the sale of goods contracts.

Since the convention was not created to impose barriers in trade across the states but to remove them, it ensures promotion and development of cross border trade. Its interpretation needs to be uniform across different legal systems and cultures in order to streamline the factors of international trade. Domestic courts therefore should follow global principles in interpretation of the convention in order to achieve uniformity and predictability in litigation of inter-state trade contracts. Therefore, A.7 (1) of the CISG purports to be on top of any other legal order in matters pertaining to the construction of the convention or trade contracts. They should be interpreted in a rather global way and not domestically.

According to Article 7 of the CISG, its construction should pay close attention to three parameters in its interpretation;

i. The need to promote unity and uniformity across all legal systems in its application

ii. Its international character

iii. Obedience to uberrimafidei in international commerce.

Though the first two parameters seem related to each other, scholars opine that they would rather be treated as a consequence of each other. (36) The third point is rather special but its interpretation has stirred many scholarly arguments as to what is the exact meaning of the principle.

\section{Global Character of CISG}

It is normal or rather usual for legislative texts to cause a stir as to their precise meanings. This is usually complicated if the instrument under construction is an international instrument such as a Convention or a Protocol. The methods of construction within a particular legal system is of great importance usually relies on the legal system in which the litigation occurs. However, since the international instruments are meant to be applied by different legal systems, the legal principles in interpretation in one country cannot be used in the construction of the CISG. Neither can an international instrument be constructed in a vacuum. The best method employed for interpretation is the use of forum laws or principles of private international law. These two application procedures may as well cause a lot disunity in the jurisprudence arising out of the courts. Consequently, as scholars suggest, it would promote forum shopping.

The only sure way of achieving uniformity in interpretation of international convention is through practice. It would go a long way in outlining the principles which would be followed in the future court cases. Article 7(1) outlines the autonomous character of The CSIG and emphasizes its independence from the domestic legal system of any state. In its interpretation, one ought to underline its independent and international character. It is the intention that although the CISG is incorporated into the laws of the domestic states, it should not be held as part of the municipal legal systems as this inhibits its growth. Since its growth is solely dependent on its autonomy, any purported incorporation of the convention into the legal system of any state is not welcome.

\section{Uniformity of Application}

The autonomous nature of interpretation of international conventions is not only a consequence of its international nature but also an essential necessity. These two parts of article 7 are therefore related because they complement each other. The existence of one of these elements requires the existence of the other and therefore they are interdependent of each other. The biggest threat to construction of CISG is a tendency of reading the instrument through the eye of domestic law or the domestic legal system. ${ }^{1}$ This threatens the sole purpose of existence of the international convention, uniformity.

\section{Good Faith in International Commercial Relations}

This principle states that dealings in international contract should include fair deals to avoid injustices on the basis of technicalities. In fact, this principle was incorporated by The Vienna Convention. Many scholars opine that this principle is an addition to general principles of the construction of the convention. This principle has attracted different divided opinions as to its exact meaning since different legal systems and scholars perceive it to mean a totally different thing. However, despite all its challenges, it connotes an important aspect of interpretation of CISG. ${ }^{2}$

\footnotetext{
${ }^{1}$ Honnold John, the Sales Convention in Action - Uniform International Words: Uniform Application? (1988), pg207-208. 2 Spanogle John, Global issues in contract law (Thomson/West) (2007) pg. 6 https://books.google.co.ke/books? id=sU09AQAAIAAJ\&q=Spanogle + John,+ Global + issues + in + contract + law\&dq $=$ Spanogle + John, + Global $+\mathrm{i}$ ssues + in + contract + law\&hl $=$ en\&sa $=X \&$ redir_esc $=y$
} 


\section{SECTION I}

\section{INTRODUCTION}

The Convention on Contracts for the International Sale of Goods ${ }^{1}$ was signed and adopted in Vienna on $11^{\text {th }}$ April 1980. ${ }^{2}$ However, it did not come into force until $1^{\text {st }}$ January 1988 . This Convention regulates the concept of multinational transactions for the commerce. Among other things, the Convention seeks to remedy breaches to the principles and rules laid down by the international law tribunal on the sale of goods contracts. Such a Convention became highly relevant due to the globalization of commercial transaction, a feat highly demystified by the onset of advance in technology. The invention of mobile phone technology as well as the World Wide Web greatly enhanced global communication, increasing the speed and efficiency of the communication through platforms such as electronic mail.

The above has implied that transactions could easily be negotiated online, prices decided online and subsequently contracts concluded online without people having to travel long distances to discuss business negotiations. Since international transactions became more common place, laws regulating trade across the borders had to be enacted. That is what gave rise to The Convention on Contracts for The International Sale of Goods, (CISG) among others. This International instrument defines or rather describes concepts of essential breach, Cure and Avoidance in multinational agreements involving trade. This law only binds parties who are nationals of ratifying states to the CISG.

Several laws and principles govern contractual agreements especially the sale of goods across the International borders. Basic principles of contract law apply in the international commerce save for where expressly stated otherwise. The UNIDROIT principles govern the manner in which private firms contract across international borders and provide means by which the firms solve their disputes in case of conflicts. Among other instruments that regulate the sale of goods across the international borders include The Convention on Contracts for the International Sale of Goods, Convention on The use of Electric Communications in International Trade, 2005, The UNCITRAL Convention, The Convention on Independent Guarantees and Standby Letters of Credit (1995) among other international instruments. This article shall briefly introduce the UNIDROIT principles before discussing the main elements of fundamental breach, Cure and avoidance in sale of goods in the international arena.

\section{UNIDROIT Contracts}

The main idea for setting forth these principles was to set general rules that govern international contracts for the trade. It had become evident that conflict of laws between different nationalities bred injustice and killed trade and therefore need arose as to the need to have a unified code of general rules. The application of these rules depends on whether the contracting parties agree to the application of these rules in case of a dispute in their contract.

These principles' application may also suffice when the contracting parties agree, either expressly or impliedly, that law shall govern their contractual relations. UNIDROIT principles also apply where parties fail to choose rules, which are to regulate their contractual relationship. Since they are principles, they are essential in interpretation of congruent international instruments on multinational contract agreements. In as much as they are used in Private International Law, there applicability in domestic courts and modelling domestic laws is not limited. They therefore inform the laws governing sale of goods in local or municipal courts. ${ }^{3}$

\section{Fundamental Breach}

According to scholars, in trade contracts, there is no consensus as to the factors that are agreed to amount to an essential breach of contracts. ${ }^{4}$ An essential breach of contracts always attracts avoidance of the agreement in part or in whole. The principles of essential breach are described in Article 25 of CISG. ${ }^{5}$ However, it is well determined that circumstances as well as facts of each case shall be discussed and relevant elements of fundamental breach deduced from the foregoing facts. In light of the above-mentioned factors, the Convention provides some of the relevant factors that usually considered in determining whether an essential breach has occurred under the CISG. ${ }^{6}$

i. The character of the contractual agreement between the parties

ii. The extent or gravity of the breach

\footnotetext{
${ }^{1}$ A Convention signed in 1980 but came into force in 1988 to regulate the sale of Goods across the international borders.

2 Defining "Fundamental Breach" Under the United Nations Convention on Contracts for the International Sale of Goods Cisg.law.pace.edu, http://www.cisg.law.pace.edu/cisg/biblio/babiak.html (last visited Dec 27, 2015)

${ }^{3}$ UNILEX on UNIDROIT Principles, http://www.unilex.info/dynasite.cfm?dssid=2377\&dsmid=13637\&x=1 (last visited Oct 16, 2015)

${ }^{4}$ Review of the Convention on Contracts for the International Sale of Goods (CISG) : 2005-2006 (Sellier) (2007)

${ }^{5}$ Breach of contract committed by one of the parties which results in such detriment

to the other party as substantially to deprive him of what he is entitled to

Expect under the contract."

${ }^{6}$ Cisgw3.law.pace.edu, http://cisgw3.law.pace.edu/cisg/biblio/koch.html (last visited Oct 16, 2015)
} 
iii. The remedy-oriented approach to the problem

iv. Ability of the parties carrying out their parts of the agreement

v. The willingness or unwillingness of the parties to act on their parts of the contract

vi. Reliance or lack thereof of the other party's future performance

vii. Offer by one party to cure the breach and

viii. The ability of the cure to be effected.

\section{The Character of the Contractual Obligations}

When the contracting parties consent by conduct or expressly that any breach to a contract attracts avoidance of the contract, then the contracting parties are bound to follow the terms and conditions of the contract. ${ }^{1}$ Any breach could easily qualify as an essential contravention of the agreement. Disregard to the wishes of one party by the other would easily be classified as an essential breach. ${ }^{2}$ Lack of an express term to that effect would attract the adjudicating body to look into the vocabulary of the contract, the contracting parties' conduct and customary practice among other factors to deduce fundamental breach in a given contractual dispute.

For instance, when there is a clause in the contractual agreement to the effect that the contract should be executed within a given timeframe, the effecting of the contract out of the time limits would definitely amount to an essential breach. ${ }^{3}$ In addition, where a contract provides that the seller provides a certain quality of goods, or where the goods are meant to suit a particular use, and the interest has been communicated to the seller, any breach of such clause would naturally amount to an essential breach. An essential breach would accrue if the seller part-delivers goods after receiving cancellation of the contract. ${ }^{4}$

\section{Gravity of the Consequences as a Result of the Breach}

Gravity is mainly discussed in terms of the gross monetary injury because of the contravention, the nature of the frustration endured as well as any available remedy to cure the breach. Significance of the monetary injury as an effect of the contravention is counter checked against the overall benefit of the agreement to determine whether the breach qualifies to be termed as a fundamental breach. ${ }^{5}$ The decisive wish of the injured corporation in the contractual relationship shall also be considered in determining if a contravention qualifies as an essential breach or not.

Though the breach might have occurred, this article scrutinizes whether the breach also impaired the purpose and motive of the whole contract. If a buyer buys goods for a particular purpose and that the goods are unable to satisfy the motive for their being bought, the vendor should be accountable for essential breach of the contract. ${ }^{6}$ For instance, if goods sold are claimed by another corporation or legal person in patent or any other purpose and that the buyer is arm twisted in the usage of the goods in the manner in which they were meant to serve, fundamental breach may suffice.

Essential breach may also be deduced if the remedy-oriented approach fails in curing the defects in the breach. This approach advocates for, instead of repudiating the agreement in instances of defective goods, the buyer takes the goods and claims compensation of the extent of the breach suffered based on various elements like the value of the buyer's business and the purpose the goods were meant to serve.

\section{Inability to Perform One's Part of the Contract}

Where the object of the transaction has been destroyed, is unable to be transported or is in any manner that the contract cannot be fully executed, the breach automatically amounts to an essential contravention of the express provisions of the agreement. It is therefore capable of being declared null and void. However, the vendor or the buyer must prove that the product that has perished was unique and could not be procured from anywhere else in order to enforce the contract. Therefore, the element of uniqueness should be prominent. ${ }^{7}$

\footnotetext{
${ }^{1}$ SarcevicPetar\&Volken Paul, The international sale of goods revisited (Kluwer Law International) (2001)

${ }^{2}$ SARL Bri Production 'Bonaventure' v. Société Pan African Export, 53 Bonaventure" v. Pan African Export 5

${ }^{3}$ Delchi Carrier SpA v. Roterex Corporation, 3 Delchi Carrier SpA v. Rotorex Corp

4 Italy 24 November 1989 Court of First Instance Parma (Foliopack v. Daniplast) [translation available], http://cisgw3.law.pace.edu/cases/891124i3.html (last visited Dec 27, 2015) e Fidenza, (Case 77/89) on the 24th of November 1989 and reported

${ }^{5}$ Peter Schlechtriem and Petra Butler, UN Law on International Sales: The UN Convention on the International Sale of GOODS (SPRINGER-LEHRBUCH) (Springer-Verlag Berlin and Heidelberg GmbH \& Co. K 2008), page 304.

${ }^{6}$ Benjamin K Leisinger, Fundamental breach considering non-conformity of the goods (Sellier European Law Pub) (2007), page 7 https://books.google.co.ke/books?id=9nDN6--

VCB8C\&printsec $=$ frontcover\&dq $=$ Benjamin $+\mathrm{K}+$ Leisinger,+ Fundamental + breach + considering + non -

conformity + of + the + goods $\&$ hl $=$ en $\&$ sa $=X \&$ redir_esc $=y \# v=$ onepage $\& q=$ Benjamin $\% 20 \mathrm{~K} \% 20$ Leisinger $\% 2 \mathrm{C} \% 20 \mathrm{Fundamental} \% 20 \mathrm{breach} \% 20 \mathrm{c}$ onsidering $\% 20$ non-conformity $\% 20$ of $\% 20$ the $\% 20$ goods $\& f=$ false

${ }^{7}$ Michael Maggi \& Patrice Fraccio, Review of the Convention on Contracts for International Sale of Goods (CISG) (Sellier) (2005)
} 


\section{Refusal to Perform or Unwillingness to Perform}

When one party expressly or impliedly, refuses to do its part of the agreement, it accrues to an essential breach. For example, where the vendor refused to transport goods which have been paid for or the buyer utterly declines to pay for delivered goods, it amounts to an essential breach. In order for refusal to amount to essential breach, action should not have been caused by the action or omission of the other contracting party.

\section{Seller's Right to Cure}

Article 37 of the Convention on Contracts for International Sale of Goods provides that the vendor have the right of curing any defect in the goods provided that such a cure does not inconvenience the buyer in any way while enjoying quiet enjoyment of his property. ${ }^{1}$ The vendor retains the right to correct the mistakes in the goods before receiving formal notification from the buyer about the defect or avoidance thereof. However, this does not limit the buyer from claiming compensation in terms of restitution, injunction, specific performance or even damages for the breach and inconveniences caused by the essential breach. The right to cure usually ends on the date specified to be the date of delivery in the agreement. Furthermore, the convention bars any purported exercise to cure which is not authorized by the buyer.

\section{Avoidance}

For a legal agreement to be avoided in international sale of goods, it follows a different path from that specified by the common law. ${ }^{2}$ In fact, fundamental breach does not only entail one to breach warrants or conditions but a substantial breach as discussed herein. ${ }^{3}$

The provisions of Article 25 of The CISG usually cater for an avoidance declaration. The first provision of an effective avoidance is its communication to other party in terms of a notice. A contract can only be avoided if there is an essential breach and one need not deduce any other reason for avoidance. ${ }^{4}$

Avoidance of an agreement has the sole effect of setting free the parties from their contractual obligations. However, avoidance has not the effect of barring a party from claiming damages as compensation for contravention of the agreement. Restitution applies to both parties after the declaration of avoidance. If restitution is impossible, a party, more so the buyer would usually claim his action for a declaration of repudiation of the agreement. This is because the buyer cannot offer restitution to the vendor hence may lead to an injustice. However, for the sake of justice, exceptions exist in every rule. First, the buyer may not dissociate from his right of terminating the agreement if it is not his fault or negligence that he is unable to restitute the goods seller bought in their favorable or original condition.

In addition, under Article 28, if the commodities perished because of examination, the buyer retains the right of repudiating the agreement. Thirdly, in the event that buyer discovers later that the goods had a defect but have been consequently sold in the buyer's premises, he/she still retains his right to avoiding the agreement but necessary modifications as to restitution. Interest on the money paid by the buyer shall have to be paid with interest by the vendor in case the contract is voided. In the filing of suit in the avoidance, the party filing should ensure that the convention of limitations. The relationship between essential breach, cure and avoidance in CISG is very strong and worth legal analysis.

\section{SECTION II}

\section{CISG Dissected; Remedies for Breach of Contract}

The CISG gives a variety of remedies in case there is a contravention of a sales agreement. These remedies include cure, avoidance, specific performance, substitution and repair of the goods, price reduction, and additional period to perform among other remedies. This article is going to concern itself with the detailed analysis of the remedies of cure and avoidance.

\section{Remedy of Cure}

The purpose of this section is to review the scholarly opinion about the relation between the right of a buyer in avoiding a contract, as per the provisions of 49 (1) and the right of the seller right in curing the defects, as established under article 48 (1) of CISG. The analysis will additionally entail detailed reference to foreign cases and legislations. It is noteworthy that different jurisdictions have taken varying approaches to the issue of the relationships between fundamental breach, cure, and avoidance. Should fundamental breach by the buyer be given the viewpoint of the right of the seller to offer to cure the defects arising from the breach? The question is the concern of this section with reference to the differing scholarly opinions and court decisions from different jurisdictions.

\footnotetext{
Ibid Supra note 15.

${ }^{2}$ Burnett Robin et al., Law of international business in Australasia (Federation Press) (2009) pg. 33

${ }^{3}$ Leisinger K Benjamin, Fundamental breach considering non-conformity of the goods (Sellier European Law Pub) (2007) pg. 143

${ }^{4}$ Di MatteoLarry A, International sales law (Cambridge University Press) (2005) pg. 135
} 
The contemporary sale of goods law has evolved with most of its developments being imitations of the common law principles guarding the sale of goods contracts. The right of a non-conforming party to cure his failures of non-compliance; if such cure will not cause hardship or unreasonable delay to the innocent party is a common development. Some of the CISG provisions and those of the PECL are examples of these common law developments.

There are several reasons that are given as justifications for the developments. Some of the reasons that many people take to qualify the excuses include good faith, risk allocation, and relational approach that calls for a shift from the strict adherence to the latter of the law to the analysis of the interests involved.

Noteworthy is the fact that the rights of curing under the CISG and the PECL differ significantly in their principle approach as well as in the privileges and rights granted under them. The main distinction between the two conventions may be that the PECL applies to all contractual transactions while the CISG applies exclusively to those agreements that concern sale of goods. What distinguishes the requirements under the two conventions, that is the sale of goods agreements and the general contracts, lies primarily in their considerations. Concisely, a general contract entails a binding and enforceable agreement between two parties. However, in trade agreements, the consideration given in exchange of the offeror's offer is money while a general contract will have a wide range of considerations.

Despite the foregoing, the right of the vendor in curing defects in a contractual agreement is intricately interwoven with the right of the buyer to avoid such a breached contract. Additionally, the right of a buyer of avoidance is intimately related to article 25 of The Vienna Convention that stipulates circumstances under which fundamental breach is likely to arise.

\section{Review of the Relevant Provisions}

The provisions of article 35 of the CISG put the seller of goods under an obligation of ensuring the quality; quantity of the goods supplied meets the descriptions given under the contractual agreement. Additionally, the style in which the goods are packaged or contained ought to be precisely and exactly as the agreed mode under the contract. Failure to meet the requirements of the aforementioned provision of the CISG, the convention will hold the seller to have acted in breach of his mandatory duties under the agreement. The contravention is clearly elucidated under article 36 of the convention. Further, the provisions of articles 41 and 42 require that the goods should be free from any encumbrances. However, the convention recognizes and outlines the right of the vendor in curing the defects in circumstances that the seller of the goods make the delivery of the goods either before or after the delivery date or in cases where he fails to meet other contractual obligations. These rights to cure by the seller are provided for under article 48 (1) of the convention.

\section{The Right of the Seller to Cure Defects: Article 48}

The stipulations of the article mean that the vendor may have a chance to remedy in case there is a failure to meet his part of the bargain under the agreement. The expenses of meeting the remedy of the failure are to borne by defaulting party; seller. There is a conflict as to whether the right of the vendor in curing should be available even after the date meant for the delivery has lapsed ${ }^{1}$. The Convention allows this remedy for so long as the seller does not cause unreasonable delay, inconvenience, or cause the buyer to suffer some uncertainty.

\section{Provisions of PECL Article 8:104 \& 9:303}

Article 8:104 of the PECL also gives the contracting parties a right to cure any aspects of the contract that are not in conformity with the requirements under the contract. The article such cure in cases where the non-conformity is noticed before the date of performance. Article 8:104 of the PECL is, therefore, a counterpart of article 37 of the CISG. There is little controversy as to the validity and applicability of article.

However, the second clause of article 8:104 faces a lot of controversy in a similar manner that article 48 (1) of the CISG is controversial. The provisions of the article allow the non-conforming party some time to cure his failure to meet the obligations under the contract even after the lapse of the date of performance under the contractual agreement.

\section{The Point of Scholarly Divergence}

Several scholars argue that cure of non-conformity will defeat the whole purpose of freedom of contract. The convention requires the contracting parties to act in good faith ${ }^{2}$.A buyer has a right of considering an agreement as having been repudiated in case the seller has fundamentally failed to commit his part of the bargain under the contractual agreement. However, the international courts, while applying the CISG, give the buyer limited ability

\footnotetext{
${ }^{1}$ Pursuant to Art. 37 CISG, the seller may cure the non-conformity as long as the cure does not greatly inconvenience the buyer. However, the buyer has a right to claim damages for those non-conformities that are not curable by the buyer. After the date of delivery, the cure will only apply with strict regard to the provisions of article 45 and 48 of the CISG.

${ }^{2}$ Michael Maggi \& Patrice Fraccio, Review of the Convention on Contracts for International Sale of Goods (CISG) (2005), page 8-16.
} 
to repudiate the contract ${ }^{1}$. In cases of breach, the CISG have extraordinary wide powers to order the vendor a right to repair the contract. ${ }^{2}$ The international tribunals only allows the buyer to repudiate the contract once is evidenced that there is a significant breach of the agreement so that the buyer will not be fully compensated by the cure. The proposal that no reservation should be added in favor of article 49 was rejected at The Vienna Conference during the drafting of the convention. The reservation sought to strengthen the buyer's right to cure. This is an express implication that the right of avoidance or repudiation of a breached agreement cannot be impaired because the seller retains a limited right of cure ${ }^{3}$.

Some scholars opine that the right of cure ought not to be granted arbitrarily. Right of cure should only be construed as possible in the cases with an offer to cure 4 . Honnold, further, avers that the entitlement of the buyer in avoiding or repudiating an agreement should be construed with strict regard of the seller's willingness or unwillingness to cure the defects caused because of non-conformity. ${ }^{5}$ In case the non-conformity is not severe to an extent that cure will be sufficient remedy, the buyer will not stand to suffer damage or hardship in case the seller cures the contract ${ }^{6}$. This is because the buyer's expectations in the contract are likely to be met after such a cure is implemented ${ }^{7}$.

Will also supports the position that the seller should be given a chance to remedy the breach that he has caused even in circumstances where the breach is fundamental ${ }^{8}$. The main reason for this proposition is to avoid a lot of uncertainty in the business transaction so that the buyer will not be certain when the seller will cure the breach and when he will not. Consequently, the buyer seems to be put at the mercy of the seller. A contract could therefore move from being avoided to curable as days went by. The consequence is that the innocent party is put at the mercy of the defaulting party. To shift the burden of uncertainty from the innocent party to the party under the obligation to cure, Will suggest that all breaches should be curable; even the fundamental breach ${ }^{9}$. The certainty will surface in that in case the seller fails to cure the breach, the buyer will automatically avoid the contract ${ }^{10}$.

Huber agrees, with reservations, that there is need for a right on the side of the vendor in curing when construing avoidance and the entitlement to provide a remedy according to the requirements of A.48. In his reservation, he opines that there are some certain special circumstances when the buyer has a legitimate interest that justifies an entitlement to repudiate (avoid) the agreement without consideration of the right of the seller to remedy the defects. The special entitlement to repudiate will emerge depending on the gravity of contravention and the agreements as per the contractual requirements ${ }^{11}$.For example, if the contractual agreement stipulated that there should be no any kind of deviation, rights of the vendor to cure may be limited. Additionally, he opines that the buyer ought to be able to repudiate a contract without consideration of the right of cure by the vendor in cases where the buyer has no more confidence in the seller because of some unscrupulous acts by the seller which may include, but not limited to, deception. ${ }^{12}$

The possibility of establishing a pellucid meaning of 'essential breach' that warrants avoidance and a mere breach that warrants cure is elusive and of great magnitude. The question that continues to blow the minds of scholars is; 'is the seller's breach of the contract fundamental if it can be cured?', 'is the breach still fundamental if the buyer subsequently cures it as per the requirements of article 48 ?'13

Some discrepancies have been pointed out that exist between article 46 (2) and article 48 of the convention. The former article give the buyer a right to demand for substitute goods in case there is a breach while the later gives the seller a leeway to cure the non-conformity. In the circumstances that the buyer wants the remedy from the seller to be in form of substitute goods, as per the provisions of article 46 (2), the vendor is not denied the right of curing the defects in the contractual agreement notwithstanding the fact that the contravention was fundamental or not. ${ }^{14}$ The buyer will not only be barred from demanding for substitute goods from the seller but also that he will be stopped from trying to avoid the contract. ${ }^{15}$

${ }^{1}$ Michael Maggi \& Patrice Fraccio, Review Of The Convention On Contracts For International Sale Of Goods (Cisg): 2003 2004 (Pace International Law Review Ed., Sellier, Cop 2005), Page 178.

${ }^{2}$ Joseph M Lookofsky, Understanding the CISG in the USA (2004), page 210-211.

${ }^{3}$ Huber, The CISG A new text book for students and practitioners, page 222.

${ }^{4}$ JOHN HONNOLD \& HARRY M. FLECHTNER, (4th ed. Kluwer Law Int'l 2009) [hereinafter UNIFORM LAW FOR INTERNATIONAL SALES UNDER THE 1980 UNITED NATIONS CONVENTIOn], page 295-297.

5 Ibid.

${ }^{6}$ Honnold, Uniform Law for International Sales under the 1980 United Nations Convention, 3rd ed. 1999, § 184. Huber, The CISG A new

text book for students and practitioners, page 224

${ }^{7}$ Ibid, Page 320

${ }^{8}$ Christoffer Permats, Seller's Right to Cure under the United Nations Convention for the International Sale of Goods (CISG), 2011, Page 29.

${ }^{9}$ Ibid, page 30 .

${ }^{10}$ Ibid, page 30

${ }^{11}$ Huber, The CISG A new text book for students and practitioners, page 223

12 Ibid.

${ }^{13}$ Ibid, Page 222.

${ }^{14}$ Ibid, page 225

15 Ibid. 
Koch, on the other side, believes that article 49 give an express implication that the buyer reserves an express right to remedy the defects in a contract, in case of an omission to perform his part, outweighs the right of the vendor to cure. According to him, this is true for only to the extent there was a fundamental breach ${ }^{1}$. The vendor's right to cure under article48 is only valid in so far as it conforms to article 49, in case the provisions of article 48 are to be construed by their plainly meaning ${ }^{2}$.In this respect, he considers the right of the vendor of cure to be limited to circumstances in which the default is not significant. In case the contravention is essential, the right is limited to the circumstances where the buyer has not expressly exercised his right to repudiate. To fortify his take, Koch cites the provisions of article 50, which states that the right of the seller to remedy the failure will the right to cure under normally prevail over the entitlement to reduce the price. Accordingly, if the drafter wanted the right to remedy to prevail over the legal entitlement to repudiate, they would have drafted the convention to reflect the same position. Koch holds that if the voluntary agreement to remedy the defect is the ultimate determinant of the existence of fundamental default, there will be a theoretical and practical problem because an offer to cure that is supposed to have a retrospective application will cause frustrations to the existing acts to avoid. He suggests that the only remedy to this is to ensure that there is imposition of a duty on the side of the buyer to promptly notify the vendor about the breach and in addition give him a chance to give an offer to cure, which offer will invalidate the application of avoidance in a retrospective manner. ${ }^{3}$

Chengwei also holds the view that the buyer retains right to avoid a breached agreement that is of significance when construing the right of the seller to remedy in case there is a breach. ${ }^{4}$ His argument is that the convention does not place the burden of establishing the willingness of the vendor to cure the contravention on the shoulders of the buyer. Following this, he opines that the vendor is obligated to provide a remedy when, and only when, he has not moved to avoid the contract. ${ }^{5}$ Additionally, the buyer is entitled to demand for a cure from the seller 6

\section{Case Law on the Right of the Vendor to cure Vis a Vis the buyer's Right of Avoidance}

Courts from different jurisdictions have given varying interpretations on whether the seller deserves a chance to remedy the defects in case the default has not been declared a significant breach as per the stipulations of article 25 of the CISG.

The first case that dealt with entitlement to remedy and fundamental breach under the CISG came in the year $1989 .^{7}$ The seller was not able to effect delivery of the goods at the contractually agreed time. The court was faced with the difficulty of determining if buyer was right to repudiate the agreement for fundamental default in the performance of his part. The court analyzed the correspondence between the two parties and the agreement reached under the contract. The buyer had categorically expressed in the agreement that delivery was to take place between 10 to 15 days of the agreement. However, the delivery was effected more than two months later after the agreed date. The court found that time was of fundamental importance in the present case. Accordingly, the buyer was allowed to repudiate the contract as per the provisions of article 49 (1) (a).

A Germany court was also faced with the question of determining whether late delivery by the seller amounted to fundamental breach. ${ }^{8}$ This was an agreement between a German and another in a different country. The contractual agreement was to the effect that delivery by the seller was to be done soonest possible. Delivery ought to have been effected immediately after the payment of $20 \%$. The $20 \%$ of the total cost was paid upon conclusion of the agreement. The seller supplied the goods (mobile phones) after four days. The buyer had already resold the phones to another dealer after by the fourth day. Two days later, he issued a notice of avoidance to the seller. The court found that the buyer had a right to repudiate the contract. The main reason for this was that time was of primary significance to the contract. The evidence to this effect was the fact that there was an agreement for delivery to be made immediately the $20 \%$ was paid. The question that the seller had no

\footnotetext{
${ }^{1}$ Ibid, Supra note 8 , at page 32.

${ }^{2}$ See also An International Approach to the Interpretation of the United Nations Convention on Contracts for the International Sale of Goods (1980) as Uniform Sales Law: A Comparative Approach 131 (John Felemegas ed., Cambridge University Press, 1st ed. 2007). and; Williams, "Forecasting the Potential Impact of the Vienna Sales Convention on International Sales Law in the United Kingdom," Pace Review of the Convention on Contracts for the International Sale of Goods (Cisg), Kluwer Law International (2000-2001), 9, at IV.C.3, also available online at $<$ http://cisgw3.law.pace.edu/cisg/ biblio/williams.html $>$.

${ }^{3}$ Ibid.

${ }^{4}$ Chengwei, Cure by Non-Conforming Party: Perspectives from the CISG, UNIDROIT Principles, PECL and Case Law, section 3.3, available at http://www.cisg.law.pace.edu/cisg/biblio/chengwei1.html http://cisgw3.law.pace.edu/cases/040421g3.html, see also Germany 24 April 1997 Appellate Court Düsseldorf (Shoes case), available at: http://cisgw3.law.pace.edu/cases/970424g1.html, where the court found that goods of seasonal character or those that are perishable can also provide sufficient ground to establish that time is of the essence and justify repudiation/avoidance. However, the court concluded that the circumstances in the case did not indicate that the goods were of seasonal character.
} 
way of knowing that the buyer had resold the goods was found by the court to be irrelevant.

The ICC arbitration decided a case in the same year that involved a Chinese seller and an Australian buyer. ${ }^{1}$ The agreement entailed the sale of scaffolding fittings. When the buyer realized some part of the fitting were not as per the contractual requirements, he sought to repudiate the contract while the seller sought to cure the contract by providing substitute goods. The arbitration realized that the non-conforming to the subject was substantial. It was held that substantial nonconformity of the goods of the contract was a breach. The breach was fundamental as per the $\mathrm{CISG}^{2}$. In this case, the court held that in any circumstance the delivery date has lapsed, the seller could only cure the defects if express consent of the buyer is sought. The court allowed the buyer to rely on the provisions of article 49 (1) (a) and article 52 (2) to effect avoidance. Courts give precedence of repudiation over cure in these instances.

In a different case adjudicated in Swiss between a seller from Swiss and a buyer from German, the court found against the buyer on the ground that he had wrongly avoided the contract. ${ }^{3}$ The contract was on inflatable triumphal arches, which were to be used by the buyer during an entire race season. However, they collapsed after some few days due to the manufacture defects. The seller sought to cure the breach. However, two weeks later, the buyer sought to avoid the contract. The court found in favor of the vendor; that the seller could easily remedy (cure) the defects without causing much inconvenience to the buyer. Additionally, the seller had responded concomitantly and contemporaneously to remedy the defects. Further, the court held that fundamental defect could not amount to essential breach in cases where such defects are remediable and the seller is willing to do so.

The Netherlands court of appeal, in another case, was faced with the issue of determining whether the goods that failed to conform to the contractual requirements amounted to a contravention of the agreement that would warrant avoidance. ${ }^{4}$ In this case, it was held, for a breach to be considered as fundamental as per the provisions of article 25 of the CISG, it must be shown that cure would result to unnecessary delay or inconvenience the buyer. The learned bench noted that the rationale behind the vocabulary of the article is that the seller is entitled under article 48 (1) to rectify his in equities in meeting the obligations even after the date of delivery under the contract had lapsed as stipulated under article 48 (1).

Also in another case ${ }^{5}$, the buyer was denied a right to damages or reduction of the purchase price because he had refused to accept the seller's offer to cure. ${ }^{6}$

Most of these cases involve the degree to which the vendor is retains his right to cure the defects in a contract after the expiry of the date of performance. The cases support the position that avoidance should be construed from the viewpoint of the seller's likelihood to offer to cure.

\section{Remedy of Avoidance}

Avoidance is a remedy provided for under of the $\mathrm{CISG}^{7}$ under some certain special circumstances. The special circumstance in particular case arises in cases where the vendor contrives an essential element in the contractual agreement. Additionally, a buyer may rightfully avoid a contract under the CISG $^{8}$ if the seller or the party that is in breach of its obligation fails to perform their part of the obligation during the additional time given ${ }^{9}$.Avoidance is equivalent to rescission under different jurisdictions. However, scholars opine that in case the time set by the buyer is unreasonably short, failure to perform contractual obligations within the timeframe would not amount to essential breach hence avoidance is avoided as well. Instead, it will trigger an automatic extension of time to amount to what will normally be construed as reasonable time ${ }^{10}$.

\section{Circumstances When the Buyer Loses the Right to Avoid under the CISG}

There are five circumstances when the right of a buyer loses his right of avoiding a contract. The first situation, which is the most controversial of all ${ }^{11}$, is when there is a right for the vendor in curing the agreement. The

\footnotetext{
${ }^{1}$ CLOUT case; CLOUT case No. 304 Arbitration-International Chamber of Commerce No. 7531, 1994. available at: http://www.unilex.info/case.cfm?pid=1\&do=case \&id=139\&step=FullText

${ }^{2}$ Article 25 of the CISG

3 Switzerland 5 November 2002 Commercial Court of the Canton of Aargau (Inflatable triumphal arch case), available at: http://cisgw3.law.pace.edu/cases/021105s1.html

${ }^{4}$ Netherlands, 7 October 2008, Gerechtshof [Appellate Court] Arnhem (Arens Sondermaschinen GmbH v. Smit Draad / Draad Nijmegent B.V.), available at: http://cisgw3.law.pace.edu/cases/081007n1.html

${ }^{5}$ Oberlandesgericht Koblenz [Appellate Court], Germany, Acrylic Blankets Case, 31 January 1997.

${ }^{6}$ Neumann and Thomas Neumann, The Duty to Cooperate in International Sales: The Scope and Role of Article 80 Cisg (Sellier European Law Publishers 2012).

${ }^{7}$ Aricle 49 of CISG

${ }^{8}$ ibid

${ }^{9}$ Articles 49 and 47 of the CISG provides that a party who is innocent in the case of a fundamental breach of a contractual obligation may claim avoidance.See alsoLisa Spagnolo, Cisg Exclusion and Legal Efficiency (Kluwer Law International 2014 ), page 49.

${ }^{10}$ Peter Huber and Alastair Mullis, The CISG: A New Textbook for Students and Practitioners (Sellier - European Law Publishers GmbH 2007), page 354

${ }^{11}$ Gabriel Moens: and Moens Gabriel, International Trade and Business Law Review: Volume XI 118 (Gabriel Moens and Roger Jones eds., Routledge Cavendish, 1st ed. 2008).
} 
provisions of article 48 give room for late delivery. As discussed earlier, because the cure under the article is subject to article 49 provisions, commentators hold the view that the buyer's right of avoidance takes precedence ${ }^{1}$.Such commentators further opine that essential factor of the contravention should be given an objective analysis without thinking about the probability of the breach being cured ${ }^{2}$. On this count, the vendor's right to rectify breached contract is under restriction to apply only to minor defects of the contract. This reality makes the application of article 48 negligible.

However, other scholars argue that in the buyer's exercise of his right to avoidance, regard shall be had to any offer to cure having been made. The rationale behind this argument is the fact that the ability coupled with the willingness of the seller to cure a breach, however fundamental the breach may be, is sufficient to ameliorate the defects in the contract. This argument is limited to the circumstances that the cure will be done without causing inconvenience to the buyer. Basing on this, the buyer should be cautious before rushing to seek avoidance of the agreement yet the cure is feasible.

The second circumstance occurs where the seller has requested the buyer for a chance to cure the breach but the buyer fails to reply to the request. Under this circumstance, the buyer will be bound to accept the cure even when it is pellucid that that the conditions under article 48 of the $\mathrm{CISG}^{3}$ that would only warrant a cure are not met. If the seller takes to cure the breach in such cases of silence from the side of the buyer, the latter is barred from causing any interference to the seller for the period he indicated in his offer to cure. The buyer's right to avoid can only be exercised after the period of cure has lapsed without successful results from the seller.

Thirdly, the buyer will lose his entitlement to repudiate the contract if he does not inform the seller of the substandard nature of the goods within a reasonable time ${ }^{4}$. This will happen in all cases where the buyer unreasonably delay to notify of any nonconformity that he has noticed or those that he ought to have noticed under normal circumstances ${ }^{5}$.Additionally, the purchaser loses the right of repudiate or avoid in case he fails to notify in due time, the any third party rights in the goods. Fourthly, the buyer is likely to lose his right of repudiation if he does not communicate to the seller within a reasonable span of time about his intention to avoid the contract after delivery. This is in case it was a late delivery. Further, in case the avoidance is sought basing on the non-conformity, other than late deliver, the buyer should communicate such non-conformity as soon as he notices the non-conformity or reasonably possible time to discover the non-conformity. Any deviant from this general requirement will render the claim of avoidance voidable to the vendor. ${ }^{6}$ What is reasonable time is determinable on a case to case basis.

Finally, the provisions of article 82 (1) of the CISG precludes the buyer from seeking to avoid a contract if he has handled the contractual goods in a manner that renders substantial restitution impossible. However, the convention ${ }^{7}$ purports that impossibility of restitution may not shield or limit the buyer's right in avoiding the contract if conditions rendering restitution impossible did not emanate from the actions or omissions of the buyer $^{8}$.An instance is perishable goods which are prone to perish naturally. It should be noted that declaration of the intention to repudiate an agreement is of essence if at all the avoidance is to have any legal effect ${ }^{9}$.

\section{The Right of the Seller to Avoid a Contract ${ }^{10}$}

The CISG equally allows the seller a right to repudiate an agreement in case the buyer falls fundamentally in fulfilling his obligation. Article 61, which is more or less an imitation of article 45, allows the seller to claim damages, specific performance or even avoid the contract in case there is an essential breach by the buyer. Just as the provisions of article 49, article 64 requires avoidance to be an option for the seller only in the cases of a fundamental breach.

The first instance where the seller is granted the right to avoid a contract is provided for under article 64 (1) (a) ${ }^{11}$. The article provides that a seller is entitled to repudiate or avoid a contract in case the buyer is in a fundamental violation of his contractual obligation ${ }^{12}$. Monetary loss does not constitute an element to determine essential breach. In case the buyer fails in this obligation and delivery is delayed because of the failure, the vendor reserves the right to avoid the contract. ${ }^{13}$

The second instance where the seller can repudiate the contract is provided for under article 64 (1) (b).In

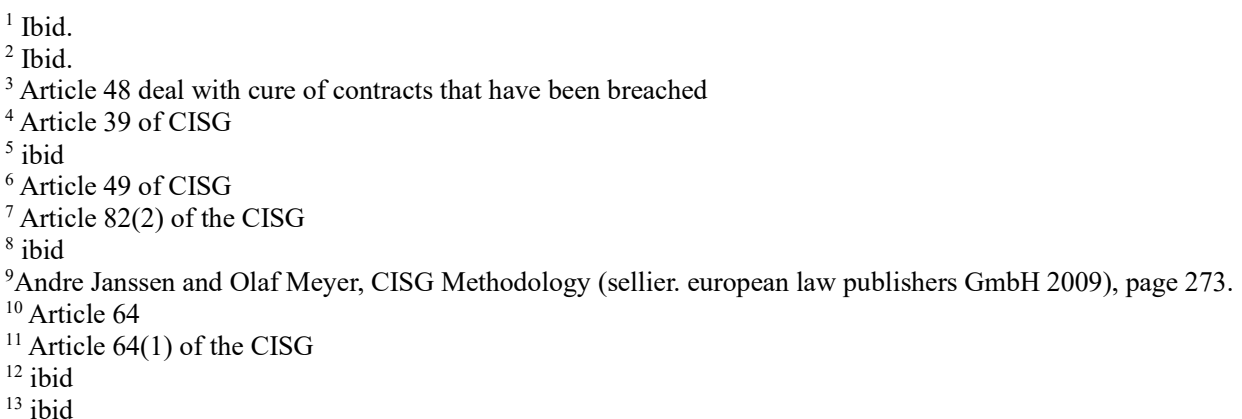


this particular provision, the seller is entitled to treat the contract as having been breached significantly in instances where the buyer fails to meet the Nachfrist Ultimatum principle. The section requires the seller to add time during which the buyer will amend the defects in the agreement. Unless the buyer has expressly notified the seller that he cannot fix the defect within the period provided, this remains the position of the law. The provisions grant a right to the seller to declare the contract as avoided in case the buyer expressly refuses or does not cure the contract within the set period.

\section{Circumstances When the Seller Lose the Right to Avoid a Contract}

The seller will always have the right to repudiate a contract unless and until the buyer pays the price in full. Additionally, it is a general requirement that the price be paid in full, even in circumstances where the price is to be paid to in installments. However, article 64 (2) provides circumstances under which the seller may lose his right to avoid the contract. The convention makes a distinction between late performance and other breaches by the buyer when determining the right of the seller to avoid a contract. Late performance means the buyer has met his part of the contractual obligation, however, this is done after the lapse of the date of performance. Other breaches include circumstances where the performance by the buyer is still outstanding. In the case of late performance of the contract, the seller will lose his right of avoidance as soon as it is intimated to him that the buyer has performed his part of the bargain that is paying the price.

\section{Scholarly Commentary on Fundamental Breach}

Prior to the adoption and accession of this convention, scholars debated as to the factors that would justify a claim being a fundamental breach. They agreed that the factors to justify a claim for an essential breach would be deduced from each case. The scholars agreed to disagree as to the factors that would justify the extent to which a breach would be termed as an essential breach of the agreement. Therefore, the judge has a wide discretion to apply a wide range of literature and depend on the prevailing facts in determining whether a certain action is justifiable to be considered an essential breach of the agreement.

The relevant elements to consider in the determination whether an essential breach ${ }^{1}$ has occurred are introduced albeit shallowly in this article. They include; the nature of obligations imposed by the contracts ${ }^{2}$, the gravity of loss suffered because of the contravention, the efficacy of remedy-oriented approach, the ability of the contract being performed, the willingness or unwillingness to perform his part a contracting party among other factors.

Most scholars opine that A. 25 of the CISG assumes that a party in contravention of the agreement foresaw the effects of the contravention even before undertaking to breach the contract. Schlechtriem opines therefore that fundamental breach accrues not only on the effects of the contravention but also on the foreseeability of the consequences on adverse party. ${ }^{3}$

Scholars in international law opine that non-foreseeability of the consequences cannot be claimed or cited as a defense nevertheless. Provided that the consequential harm has already occurred and that it falls within the realm of fundamental breach, the doctrine of res ipsar loquitur would apply. It is assumed that under such circumstances, a reasonable man in similar circumstances would naturally foresee the adverse effects of such actions.

Scholars take different positions as to the as to the point at which the relevance of foreseeability is to inferred. Some take it from the injury arising from the injured party's expectations whereas other would rather wait until the agreement is concluded in order to discern if indeed there had been a fundamental breach of the contract. They hold different positions because some scholars find no need to include time frame on contracts which do not have time limits with them. Whereas other scholars are usually protective on the injured parties, others would rather advocate for the rights of the villain party.

\section{SECTION III}

There is no doubt as to the effects of $\mathrm{CISG}^{4}$ on the domestic laws of many states. It is indeed true that the CISG has created a completely new system of substantive laws which now govern the system in which the international relations pertaining to sale of goods are concerned. The CISG does not replace the domestic laws governing trade agreements but only applies to certain extent in the international relations that certain only to sale of goods agreements and no more. Scholars researching in this field therefore need to research about the domestic legal system of their country, the international realm of it as well as some few countries for comparison

\footnotetext{
${ }^{1}$ Michael Furmston and Furmston, Sale \& Supply of Goods 3/e (Commercial Law) (Routledge Cavendish, 3d ed. 1999 ), page 159.

${ }^{2}$ Joseph M Lookofsky, Understanding the CISG : a compact guide to the 1980 United Nations Convention on Contracts for International Sale of Goods (Wolters Kluwer ; Frederick, MD 3) (2008) pg. 115-119

${ }^{3}$ Morrissey Joseph F et al., International Sales Law and Arbitration : Problems, Cases and Commentary (Kluwer Law International, cop) (2008) pg. 224-227

${ }^{4}$ Convetion of international contract on sale of goods, 1980
} 
purposes. This task, however involving proves to be nutritious in the academic realm.

This part shall delve into the theoretical framework of the multinational trade contracts. Importance shall be accorded to A. 23, 48 and 49 of the CISG. Therefore, the article shall rely on secondary sources such as books, scholarly articles and journals to discuss the history and development of international laws governing international contracts pertaining to the sale of good as well as the motive behind the formation of these laws. Afterwards, the article shall seek to analyze the effect of these laws on the world states through case law and scholarly commentary. In the same breath, the applicability or rather the acceptance of the convention is of key importance.

Of essential importance are some instruments which are discussed albeit briefly by this article. These are important in the study of the CISG in relation to fundamental breach, cure and avoidance. The trade usages, the provisions of the CISG (a. 25, 48 and 49), scholarly commentaries on these provisions, case law, UNIDROIT principles on the items of research, lexmercatoria, official commentaries on the text among others. It is therefore trite and in order that the article starts with the history of the convention before the other elements are discussed.

\section{Background to the CISG, 1980}

The significant part of history started on $10^{\text {th }}$ April, 1980 when representative diplomats from about 62 states adopted uniform rules to govern international trade. This rules had an almost immediate impact since eleven states had ratified them by December the same year. These states include; Argentina, USA, Egypt, China, Hungary, France, Yugoslavia, Italy, Zambia, Lesotho, The Syrian Arab Republic among others. As of 2012, about seventy-eight states have ratified the convention ${ }^{1}$. This represents more than a third of the total nations on earth. In fact, it is a show of overwhelming support for the convention. The contracting states in this convention account for excess of two thirds of world trade. They therefore drive the world economy. Notable world trade hegemonies that had not ratified the treaty include Brazil, United Kingdom, South Africa, India, Hong Kong and Taiwan. However, by 2012, Brazil was in its final phase in ratifying the CISG.

Works that culminated into this Vienna Convention did not just start in 1980. In fact, efforts to make laws to regulate international trade back dates to early 1920s. UNIDROIT has requested a bevy of scholars to draft rules that would govern international relations in sale of goods agreements. ${ }^{2}$ These scholars presented their first draft in 1935. However, the project was hampered by the World War II and therefore the project stalled. In 1952 , a conference involving diplomats from twenty-one states resolved that the scholars would continue with their scholarly drafting. This conference in Hague appointed a commission that produced two drafts to the effect of making the international agreements of sale of goods uniform. However, the effect of these convention was minute since they were ratified by very few states. Only 9 countries ratified the treaty.

Ernst Rabel an Australian academic contributed significantly to the process of unification of the instruments. ${ }^{3}$ Having been in the commission that drafted the failed conventions, he suggested to UNIDROIT to make it their first priority to harmonize the two conventions. That having been done, he continued with the work of harmonization of the instruments later on until his death in 1955.

In 1966, the United Nation General Assembly convened a meeting and resolved to form a global committee for harmonization of the conventions (The United Nations Commission of International Trade Law, UNCITRAL). UNCITRAL convened its first meeting in 1968 and subsequently presented a draft article to the UNGA in 1978. In 1980, during the UNGA, the diplomats adopted the New York drafts in a conference held in Vienna. Since then, the signatories to the Convention have been growing steadily. Upon satisfaction of A. 99 of the CISG that on submission of the $10^{\text {th }}$ instrument of adherence, the CISG acceded into force on January $1^{\text {st }} 1988$. It is important to note the adoption of The Convention of Limitation Period in $1974^{4}$.

\section{Jurisprudential analysis; Fundamental Breach, Cure and Avoidance}

This are of the central terms in the Vienna Convention. They claim prominence in A.25, 48 and 49 of the instrument as well as other articles. ${ }^{5}$ Apart from entitling one to exercise a right to avoid a contract, Essential

\footnotetext{
${ }^{1}$ Ingeborg Schwenzer and Pascal Hachem, the CISG-Successes and Pitfalls, 57 American Journal of Comparative Law, Ingeborg Schwenzer and Pascal Hachem, the CISG-Successes and Pitfalls, 57 American Journal of Comparative Law 457, 457-78 (American Journal of Comparative Law 2009).

${ }^{2}$ Benjamin K. Leisinger and B. Leisinger, Fundamental Breach Considering Non-Conformity of the Goods (Beitrage Zum Internationalen Wirtschaftsrecht/ Contributions on International Commercial Law) (sellier. european law publishers GmbH 2007), page 28-29.

Note $(28$ - 29): The ULIS Convention best describes the elements of fundamental breach given that it is the immediate predecessor of CISG.

3 Pace International Law Review (2007) Review of the Convention on Contracts for the International Sale of Goods (Cisg), 2005-2006. Edited by Pace International Law Review. United States: Sellier European Law Publishers.:However, the process of creating a uniform jurisprudence is highly impaired in Canada. In Canada, most CISG cases remain unreported and doubts as to the leal practitioners have a gist of the convention looms.

${ }^{4}$ This formed part of the process of the unification of international laws on the sale of goods contracts

5 ibid
} 
Breach has several other repercussion. According to A.46 (1) of the Vienna Convention, one can claim to the goods delivered to be replaced. The term 'fundamental breach' ${ }^{1}$ is also discussed in article 70 in connect with other provisions of the instrument. ${ }^{2}$ When these articles are synchronized with A.70, the result maybe a bit controversial in the sense that if for instance goods delivered by the vendor, the vendor being guilty of an essential breach, get perished while in custody of the buyer, the vendor may be held to compensate the buyer nevertheless for contravention of the agreement. This is to mean that the risk would not have passed to the buyer since provisions of the agreement have not been adhered to adequately and therefore the provisions of A. 46 (2) apply.

Essential breach as espoused in A.25 also has a bearing in other parts of the CISG. ${ }^{3}$ It is therefore right to note that fundamental breach is the backbone of the convention given its wide influence on other provisions in the same convention. The most serious cases concerning the convention usually tough on essential breach and these cases usually plead the remedy of avoidance since it is the only cure available.

Fundamental breach, cure and avoidance are all related in the sense that cure and avoidance are incidental to fundamental breach. If an essential breach does not accrue, then it is highly likely that the remedies of cure and avoidance are necessary. These remedies are discussed in detail at A.48 and 49 of the convention. In fact, A. 49 , which describes avoidance of a contract is described as the harshest remedy available to the vendor in case it is granted.

Article 25 provides the judges with extremely wide discretion in its wording to decide whether particular circumstances would normally or reasonably justify fundamental breach. This wide and ambiguous discretion would almost make the innocent parties believe that they are reserve the right avoid the agreement because of a purported essential breach. This uncertainty causes delay in proceedings and therefore costs and other incidental expenses.

This thesis aims to outline the general principles espoused inessential breach as codified in A. 25 and then relate it to the other parts of the convention. Case law shall then be discussed to give flesh to the arguments. This article hypothesizes that fundamental breach is accorded too much discretion in its interpretation and therefore more likely to cause discrepancies than justice. It ought to be construed in a narrower sense so that it creates certainty in interpretation. Otherwise, an international court should be established to create coherent jurisprudence.

\section{The Structure and Meaning of Article $48^{4}$}

Cure refers to the activity by the vendor to remedy any breach of obligations even after delivery unless the cure does inconvenience the buyer. A.48 (1) entitles the buyer to claim for damages even after the cure had been carried out. This is because the cure may have caused the buyer monetary inconveniences and it would be just and mete if the inconveniences are repatriated.

In case the vendor serves a notice to the buyer requesting performance of a cure, but the buyer fails to comply within the specified time, the vendor may undertake to rectify the contravention within acceptable time. ${ }^{5}$ This notice by the seller ought to be received by the buyer so that it is effective. However, the right of rectifying under article 48 is subject to article 49.that is to imply that exercise of right of avoidance does not negate the right to remedy. ${ }^{6}$ In addition, the buyer's permission must be sought before the seller exercises the right to cure. ${ }^{7}$ However some court's decision require that the vendor must be given a chance to correct the mistake first even though it's a fundamental one. ${ }^{8}$ A breach of an agreement is rarely an essential breach if it could easily be cured. However, it is important also to note that the buyer cannot be compelled to give room for the vendor to rectify discrepancies in the goods after delivery if they may cause him inconveniences. ${ }^{9}$

\footnotetext{
${ }^{1}$ As discussed extensively in article 25

${ }^{2}$ A. $46,67,68$ and 69 of the same Convention.

${ }^{3}$ For instance article 51(2), 72(1), as well as article 73(1) and (2) were the buyer reserves the right to be supplied with substitute goods in case of fundamental breach.

${ }^{4}$ Ingeborg H. Schwenzer et al., Global Sales and Contract Law 564 (Oxford University Press, USA 2012).

Note (564): Initially, buyer's right to cure was not considered a remedy under contract law

${ }^{5}$ John O. Honnold et al., Uniform Law For International Sales Under The 1980 United Nations Convention - Fourth Edition Revised (Sold and distributed in North, Central, and South America by Aspen Publishers, 4th ed. 2009)., page 296.

Note (296): where cure is feasible, the seller's right to cure should be protected; see also Gabriel Moens: and Moens Gabriel, International Trade and Business Law Review: Volume XI (Gabriel Moens and Roger Jones eds., Routledge Cavendish, 1st ed. 2008).

Note: The buyer ought to respond to the request for cure or else the seller shall claim the right ot cure with no remedy for damages

${ }^{6}$ CLOUT, case No. 90 [Pretura circondariale de Parma, Italy, 24 November 1989] (see full text of the decision); CLOUT case No. 2 [Oberlandesgericht Frankfurt a.M., Germany,

Article 48(2), see also CLOUT case No. 304 [Arbitration International Chamber of Commerce No. 7531 1994]

${ }^{8}$ CLOUT case No. 339 [Landgericht Regensburg, Germany, 24 September 1998].

'Olaf Meyer and Ebers, European Perspectives on Producers' Liability: Direct Producers' Liability for Non-Conformity and the Sellers' Right of Redress (Martin Ebers and Andr Janssen eds., Sellier - European Law Publishers GmbH 2009), pg 225.

Note (225): The seller's right to cure is very limited. It is granted when the activity would not cause unnecessary inconvenience to the buyer.
} 


\section{Structure and Meaning of Article 25}

In the definition of essential breach, several cases have been able to describe what elements suffice to declare that indeed an essential breach has occurred ${ }^{1}$. One such case is CLOUT case No. $2^{2}$. It was held that for fundamental breach to have occurred, one party must have violated the terms of the agreement, either specifically in the contract agreement or provided in the CUISG ${ }^{3}$. In fact, any breach even if collateral has the potential of being declared an essential breach provided it causes a significant loss to the injured party ${ }^{4}$. A good example may be illustrated if an agreement specified that the gods would only be sold by the seller under the buyer's trade mark but the seller displays the goods in a trade fair without the trade mark, that should be considered an essential breach of the agreement and the remedies thereto may suffice ${ }^{5}$.

In CLOUT case No. 123, the buyer was held not to reasonably expect the seller to meet the expected standards of good specifications in the buyer's country. ${ }^{6}$ Otherwise, lack of observance of the standard could not accrue essential breach.

The burden of proof lies with the party in breach of the contract in as much as the foreseeability element is concerned. The villain party has the burden to prove that indeed the breach was not deliberate and that the consequences were not reasonably foreseeable. ${ }^{7}$ The injured party bears the onus to prove substantial loss of in expectations as well as monetary loss because of the contravention of the contract. ${ }^{8}$

\section{The Structure and Meaning of Article 499}

The contract shall be avoided in case there is an essential breach as well as failure of the vendor to deliver or expressly indicate that he will not be able to make delivery of the goods within the additional timeframe specified under Article 47 of The Convention. ${ }^{10}$ The buyer is likely to lose his right of avoiding the agreement under the provisions of Article 47 and 48 of the CISG $^{11}$. Avoidance is a remedy of last resort and is usually effective after the notice of avoidance has been issued in accordance with provisions of Article 26 of The Vienna Convention. ${ }^{12}$ Unless these reservations of A.12 and (6 are invoked, the notice of avoidance is usually in written form. Termination does not suffice from statements that claim future termination, return of goods without communication as well as a statement requesting delivery. ${ }^{13}$

Article 49 does not apply in a vacuum. If the vendor supplies non-conformity goods or goods which have third party rights, the buyer needs to communicate his grievances in addition to the breach constituting an essential breach in order to exercise avoidance. This is in conjunction with article 39 and 43 of the CISG. It was upheld in a Switzerland court ${ }^{14}$. In general, circumstances that would normally justify avoidance of a contract have to conform to the provision of a.25 of the convention. In essence, the remedy of avoidance is usually awarded as the last option if the reach could not be cured or rather repaired by any other remedy such as

In addition, it should be carried out before delivery period is over. However, this does not disentitle the buyer from claiming damages from the breach.

${ }^{1}$ Ewan McKendrick et al., Transnational Commercial Law: International Instruments and Commentary (Text Cases \& Materials) 301 (Oxford University Press, USA, 1st ed. 2007).

See also Larry A. DiMatteo, Commercial Contract Law: Transatlantic Perspectives 468 (Larry DiMatteo ed., Cambridge University Press, 1st ed. 2013)

Note (468): each case is considered on its own merits to extract elements of essential breach

${ }^{3}$ Franco Ferrari, The CISG and Its Impact on National Legal Systems (Franco Ferrari ed., Sellier - European Law Publishers GmbH 2008), pg 368-69.

Note (368 - 369): Fundamental breach is defined in Article 25. Its effects are felt in Article 48, 49, 7073 among other provisions.

${ }^{4}$ Richard Schaffer et al., International Business Law and Its Environment (Thomson/South-Western, 6th ed. 2004 ), pg108.

Note (108): Section 25 of CISG provides the difference between breach and fundamental breach. Simple breach can be remedied by damages, specific performance, injunctions etc

${ }^{5}$ United Nations Publications, UNCITRAL Digest of Case Law on the United Nations Convention on the International Sale of Go... (United Nations Publications 2008).

${ }^{6}$ CLOUT case No. 123 [Bundesgerichtsh of Germany, 8 March 1995].

${ }^{7}$ CLOUT case No. 171 [Bundesgerichtsh of Germany, 3 April 1996]

${ }^{8}$ Ibid

${ }^{9}$ Martin Davies and David V Snyder, International Transactions in Goods : Global Sales in Comparative Context 367 (Oxford University Press 2014).

Note (367): the equivalent of the buyer's right to avoid a contract for the seller lies in article 64

${ }^{10}$ Joseph M. Lookofsky, Understanding the CISG in the USA: A Compact Guide to the 1980 United Nations Convention on Contracts for the International Sale of Goods 110-11 (Kluwer Law International, 2d ed. 2004); see also Michael L. Rustad, Understanding Sales, Leases, and Licenses in a Global Perspective 310-11 (Carolina Academic Press 2008).

Note (310 - 311): Avoidance can only be claimed when there is a fundamental breach of the agreement

11 ibid

${ }^{12}$ Djakhongir Saidov and Ralph Cunnington, Contract Damages: Domestic and International Perspectives 87-95 (Ralph Cunnington and Djakhongir Saidov eds., Hart Publishing 2008)

Note $(87-95)$ : the buyer is entitled to avoid the contract in case there is a fundamental breach

${ }^{13}$ CLOUT case No. 6 [Landgericht Frankfurt a.M., Germany, 16 September 1991]; CLOUT case

No. 282 [Oberlandesgericht Koblenz, Germany, 31 January 1997].

${ }^{14}$ CLOUT case No. 196 [Handelsgericht des Kantons Zürich, Switzerland, 26 April

1995]. 
damages. ${ }^{1}$ It is essential to note that courts treat avoidance as the harshest remedy in trade Contracts. However, the consequences of avoidance of these agreements are dealt with in article $81^{2}$.

It is important to make a distinction between the unqualified right of the offending part to cure and a qualified right to cure. An unqualified right will arise in the circumstances where there is an extension of time within which the offending party is supposed to make good of his failures in the fulfillment of the obligation. On the other hand, a qualified right to cure will usually arise in the circumstances where the innocent party has failed in a way to exercise his entitlement of repudiation so that he is precluded from purporting to avoid/repudiate the contract.

The most significant right at the disposal of an innocent/aggrieved party in the circumstances of a breach of an agreement for the sale of goods is the right to avoid/repudiate the agreement. The entitlement of avoidance or repudiation is available to both the seller and the purchaser just in case either party is in breach of their obligation. The buyer has a right to avoid a contact under some certain specified circumstances under the CISG. Similarly, the seller has a right to repudiate or avoid a contractual agreement in case the buyer has failed to meet his part of the contractual requirements so that a fundamental breach is inferred to have occasioned. The right on the part of either the seller or purchaser to avoid a contract will normally frustrate any subsequent effort of the offending party to cure the contract. Noteworthy is the fact that once the right of avoidance has been exercised by the innocent party, any subsequent efforts by the offending party to cure the defect will be in vain.

Most contractual regimes have an ingrained propensity of subjecting the right to avoid a contract under the right to cure. The result is that the right to cure is given precedence over the right to avoid. As such, the offending party is immunized from the premature efforts of the innocent party to a breached agreement to avoid the contract. The offending party will have a reasonable grace period during which he must cure the contract before the right to avoid materializes.

In case the parties have entered into a post-avoidance communication, or any performance that will purport to cure the contract, such efforts will fail not unless the new communications are construed as amounting to a new offer. The new offer or contract may or may not be taken to exculpate the breaching party from previous breaches.

\section{When the Seller Knows the Specific Purpose of the Goods}

The provisions of the $\mathrm{CISG}^{3}$ requires that if there are some certain specifications that the buyer intimated to the seller at the moment of the conclusion of the contract, the goods must fit the purpose. When the buyer makes known to the buyer the purposes of the goods, it means that the purchaser is relying on the seller's knowledge of the goods. The effect is that such goods ought to meet the specification and the particular purpose.

\section{Exclusion of Liability}

The CISG relieves the seller of any liability that may have been counted on the seller under ordinary circumstances if the time at which the contract was concluded the buyer was aware of the existing nonconformity or if there is no way a reasonable person will have failed to notice such non-conformity ${ }^{4}$.

\section{The Interaction between the Remedies of Cure and Avoidance}

The point of coincidence between the right of the seller remedy the defects caused by his failure of obligation and the entitlement of the purchaser to repudiate the agreement arises some controversy depending on whether the right to cure is premised on the provision of article 48 (1) or 48 (2) of the CISG. In the cases, where the buyer has expressly or be implication accepted the offer of the seller to cure the contract, the buyer will be stopped from claiming avoidance. This is because the right of the seller to cure as provided in 48 (2) of the CISG takes precedence above the right of the purchaser to repudiate the contract. The position is founded on the provision of article 48 (2). The article provides to the effect that at any moment the seller has embarked on the task of providing a cure to the contract, the right of the seller to cure estops the buyer from resorting to any remedy that is inconsistence or that which is likely to interfere with the exercise. However, if there existed no agreement the parties, that is between the purchaser and the seller, on which the seller relied to cure the contract, the right to cure on the side of the seller is exclusively under the directions of the provisions of article 48 (1). The most significant distinction between the two provisions is that express reservation made under the article. The reservation states to the effect that the right of remedying a contract by the seller is subject to the stipulations under article 49 of the CISG. In this respect, the right of the buyer to avoid a contract will take prominence over

\footnotetext{
${ }^{1}$ Peter Huber and Alastair Mullis, The CISG: A New Textbook for Students and Practitioners (Sellier - European Law Publishers GmbH 2007), pg209-10

2 ibid

${ }^{3}$ Article 35 (2) lit. (b) Imposes additional requirements applicable in narrower circumstances compared to article 35 (2) lit. (a).

${ }^{4}$ Article 35(3) the seller is not liable under the provisions of article 35 (2) a-b if at the conclusion of the contract the buyer was aware of the existing non-conformity.
} 
the entitlement of the seller to remedy/cure the defects under the contract. In a recently decided case, the decision of the court made it hard to establish whether the buyer's refusal to offer the seller a chance to cure amounted to the main cause of the seller's supply of non-conforming goods ${ }^{1}$. In this case, the buyer, after delivering non-conforming goods, sought to cure as per the provisions of article 48 of the CISG. Despite the foregoing, the court found that the buyer could not rely on the breach to avoid the contract because he had hampered the cure ${ }^{2}$.

The implication of the reservations under the provisions of article 48 (1) simply means that the right of the seller to provide a cure to meet his part of contractual obligations will be available so far as the demands of article 49 are met. However, such a position only shifts the problem to the manner in which the wording of article 49 will be interpreted rather than solve it. The person construing the possibility of a cure has to make the consideration with strict observance of the requirements of article 49 of the CISG, in establishing whether the breach was fundamental.

However, scholars have argued correctly that the provisions of article 49 should be construed with strict consideration of whether the breach is curable under article 48, regardless of whether or not the breach is fundamental ${ }^{3}$. Legal writers and courts are currently gravitating towards this is the position. Presently, the right of a seller to cure a breach is given first consideration over the right of a buyer to cure not unless the seller has refused or totally failed to offer a cure. The only exception to this current position is in cases where the buyer refuses to agree to the cure because he has an interest that requires immediate avoidance of the contract. Circumstances as the present require that the right of the buyer to repudiate the agreement take priority without further consideration of the right of the seller remedy the defects. ${ }^{4}$ In yet another case ${ }^{5}$, the court refused to consider the reality that the purchaser had hindered the right of the seller to cure but stated that the seller could rely on the stipulations of article 80 if the buyer had thwarted his endeavor to cure.

\section{Expenses of Cure and the Associated Risks}

The cure of a contract has some associated expenses that must not be shared between the two contracting parties. The troubles and the expenses that are because of the defaulting party's efforts to cure the contract are unilateral, affecting the breaching party alone. Additionally, the performance done to cure the breach is supposed to be near the original contract as much as possible. Any costs that are incurred in the efforts of ensuring that the defaulting part is relieved the burden and costs of lawsuits are to be borne by the breaching party. Cure is more or less like a substitute for performance. Effectively, it is required that the each party should share the costs of performing its part of the obligations under the contract. The effect is the principle is applicable in the foregoing by analogy.

\section{Retaining the Right to an Award of Damages}

The fact that cure has been performed do not negate the fact that there was a violation of the agreement. Therefore, the fact that a cure is an equivalent of performance of the original contract, which makes the need for other remedies such as specific performance and/or avoidance unnecessary, the possibility of ordering for damages are not dispensed. The damages are outlined under article 74. However, an Australian court has held that cure of a contract precludes the application of all other available remedies under the provisions of the CISG ${ }^{6}$.

\section{Current Trends in Modern Transactions}

Technology has foreseen a wholesale revolution in the multinational corporation realms. Trade practices are now being run more in soft copy than in hard copy like they were before. The emergence of social media and websites has also been a hit on the in the transactional world. Modern transactions no longer need complex

\footnotetext{
${ }^{1}$ Djakhongir Saidov, The Law of Damages in the International Sale of Goods: The CISG and Other International Instruments (Intl Specialized Book Service 2008), 97.

2 See Case No 2 U 31/96 Appellate Court Koblenz (Germany) 31 January 1997 (Acrylic blankets case) http://cisgw3.law.pace.edu/cases/970131g1.html

${ }^{3}$ Peter Huber and Alastair Mullis, The CISG: A New Textbook for Students and Practitioners (Sellier - European Law Publishers GmbH 2007), 222-23.

${ }^{4}$ Peter Huber and Alastair Mullis, The CISG: A New Textbook for Students and Practitioners (Sellier - European Law Publishers GmbH 2007), 222-23.

Case No $271 \quad$ C $18968 / 94$ Lower Court München (Germany) 23 June 1995 (Tetracycline case) $<$ http://cisgw3.law.pace.edu/cases/950623g1.html $>$.

${ }^{6}$ See Austria 14 January 2002 Oberster Gerichtshof [Supreme Court], case presentation including English translation available online at $<$ http://cisgw3.law.pace.edu/cases/020114a3.html>. The court also curiously refers to cure as a "right" of the aggrieved buyer although under CISG (and PECL) the seller does not generally have an obligation to cure; she has a right to cure, as analyzed above. Had there been a buyer's right to impose cure and a seller's obligation to make one, and the seller would default on that, that would have to become an issue separate from her breach of the contractual obligation itself. Obviously, nowhere in the CISG is a party obligated to perform more than the contract stipulates. Of course, under certain conditions the buyer has a right to specific performance that needs be enforced in court (see CISG Arts. 28, 46) but that is a different matter entirely, not to be mixed with that of cure cure. Switzerland 5 November 2002 Handelsgericht [Commercial Court] des Kantons Aargau, case presentation including English translation available at $<$ http://cisgw3.law.pace.edu/cases/021105s1.html>.
} 
article work and long distance travelling. All one needs is evaluate samples online, select and pay for goods and wait for delivery. Payment is more simplified due to the emergence of the microchip technology enabled smartcards. Due to this technology, one can pay for goods anywhere in the world with the swipe of the card. Is this not interesting? That notwithstanding, the revolution has also created a raw deal of challenges for international businesses. Fraud is more rampant than before. Phishing and other cybercrimes have taken root as fraudsters camouflage as legitimate companies and end up getting the financial records of unsuspecting customers. The concept of fundamental breach, cure and avoidance are also highly affected by the incidence of the internet era.

The conventional communication systems used to notify the seller of repudiation of a contract 20 years ago is not exactly the same as today. Similarly, if a seller wanted to correct mistakes in defective goods already delivered, he/she does not need to send letters through the post office since it is likely to take long. Many states have embraced technology in their legal systems and therefore in proving transactions, electronic evidence could be adduced albeit under strict scrutiny. Nevertheless, the ease of communication has increased the number of transactions across the international borders. How would essential breach be interpreted in light of the current trends on technology? Given that any alteration to essential breach causes wholesale changes to cure and avoidance.

Multinational corporations prefer doing business online more than on the ground since online business accesses more people and a larger market base. Do computer software amount to goods worth trade under the CISG? Multinational companies such as eBay run online databases for car sales while Alibaba and Jumia specialize in general merchandise. Contracts are signed online, concluded online, repudiated online with little sense of touch between the parties. Therefore, the likelihood of fraud is high. Should the CISG be revised to include the provisions of electronic media? Does reasonable time ${ }^{1}$ from a layman point of view change due to the emergence of new technology? How does the notice requesting cure by the vendor manifest? Is email a viable way of communication or what is the conventional way to effect business communications? Such are the emerging jurisprudential questions lingering on the minds of scholars that need urgent answers.

Application of new technology in the international business transactions is a huge leap in the right direction. However, the laws are not yet prepared to oversee this huge transition. Laws such as CISG which took decades to draft are likely to remain conservative and unlikely to conform to the current trends in international business transactions. However, these trends are likely to improve more than reduce. The concept of fundamental breach, cure and avoidance being the central issues in conflicts of sales contracts would thus feature prominently. Cybercrimes such as phishing are likely to be associated with commercial transaction simply because online businesses have to be mandated to ensure tight security in order to eschew online fraudsters targeting their clients.

\section{CONCLUSION}

There exists a great interrelationship between fundamental breach, cure and avoidance. Various remedies, of which the prominent ones are cure and avoidance, can remedy a contract that has been fundamentally breached. These remedies are established under the provisions of the CISG. The SCIG is a convention that has been ratified by many states and has a universal application. However, the ways in which the provisions of the convention are interpreted in different jurisdictions is differs greatly. The difference in the interpretation is because some states choose to subordinate the convention to their domestic laws thus making its application and effect insignificant. Despite the fact that there is a great coincidence or relationship between the provisions of article 48,49 , and 35, the way they are interpreted in different jurisdictions brings about a lot of inconsistencies in the international law.

The spirit of the demands of article 48 as provided for under the CISG is rather pellucid. As per the provision, the seller has a right to remedy the defects under the contract takes prominence over the entitlement of the purchaser to repudiate a contract.

There are those people that advocate for a contractual regime whereby people have full contractual freedom. Under this particular type of contractual regime, the states and the various social institutions are expected to play an inactive role; with little or no interference with the contracting parties' agreements. The advocates of the theory of contractual freedom require that the individuals be given a chance to choose when to enter to a contract and when to rescind from the same. The state ought not to interfere with people's choices. The same motivation that drives people to entering into contracts should be the same motivations that should move the parties to honor their part of the bargain. As such, the contracting parties should always ensure that they lay down all the terms upon which the contract is to run.

The theorists of the freedom of contract find many discrepancies in the provisions of the CISG with regard

\footnotetext{
${ }^{1}$ Article 48 of the CISG provides for the seller's right to cure; see also Article 49 where after reasonable time has been accorded to the seller and he fails to cure the defects, the buyer shall exercise his right to avoid the contract.
} 
to cure, fundamental breach and avoidance. The SCIG requires that the right of the breaching party to cure the contract take precedence over the right of the aggrieved party to avoid the contract. Much as this is not the express implication of the wording of the convention, most scholars construe the CSIG to hold the position. The right to cure by the breaching seller is stipulated under article 48 . However, the cure will be available subject to the requirements of article 49 . Some scholars construe the wording of article 48 that they deny the buyer a right to repudiate a contract in case the seller has failed to meet his obligations as per the contractual terms. The main argument is that this limitation deprives the buyer of his contractual freedom. The scholars who are against this view see the courts as having extraordinarily widened mandate that infringes into the rights of freedom of parties to contract. The convention seem to force people to remain in contractual relationship even in the circumstances where it is evident that the relationship between the parties has irretrievably broken down.

Additionally, it has become lucid that the convention does not provide a clear elucidation of the instance where fundamental breach will have occurred. For example, does fundamental breach occur where the seller cannot possibly cure the contract without significantly inconveniencing the purchaser or when it is impossible to cure the defect successfully? The additional question that has been posed is whether a breach of obligation will still be considered as fundamental breach even in the circumstances where it is clear that that cure is the most suitable remedy. Additionally, if the fundamental breach is ultimately cured, will it still be construed as a fundamental breach? The answers to these scholarly inquiries remain elusive from the scholars' inquiry.

The primary rationale of commercial law is to facilitate commercial transactions rather than hamper them. As a result, the law should rightly presume that the contracting parties entered into the transaction for commercial benefits and therefore their intentions should be facilitated at all costs. In case the contract has been breached, the breaching party should be given a chance to rectify the defects, regardless of the fact that the breach is fundamental as stipulated under article 49 of the CISG convention. Additionally, because the contracting parties contracted on their own volition with maximum utilization of their freedom of contracts means that they would equally benefit from the contract if it were performed rather than if it were terminated. As a result, the courts should ensure that they gravitate towards facilitating transactions instead of frustrating them whenever they are giving interpretation to the wording of the CISG convention.

Notwithstanding the foregoing, the fact that fundamental breach, cure and avoidance are relate is well established. Cure and avoidance are remedies that are at the disposal of an aggrieve party in case there is a breach of a contract. The determination of which of the two remedies should be issued is dependent on the degree and magnitude of the breach. A mere or insignificant breach of the contract will only call for a lesser remedy. In the present case, an insignificant breach of a contract entitles the aggrieved party only to a claim that will ensure the interests in the contract are fulfilled. Such a remedy is cure. Cure will give the breaching party an opportunity to revive the contract. However, in cases of a gross breach, herein referred to as fundamental breach, the aggrieved party is entitled to the remedy of avoidance.

This article recommends that the entitlement to provide a remedy by the breaching party should take priority above the right to repudiate or avoid by the aggrieved party without recourse to the significance of the breach. This particular position will facilitate commercial transactions rather than frustrate them. In addition, the mode of interpretation the provisions of the CISG should be harmonized across all jurisdictions. The rationale for the recommendation is that technology has reduced the world into a global business. Future research should focus on providing greater specificity is required in ascertaining the degree of seriousness, detriment, foreseeability and time of foreseeability in cases of contractual breach. Also, there is a need to review the provisions of the CISG periodically.

\section{Bibliography:}

Janssen, Andre and Olaf Meyer, CISG Methodology (Sellier. European Law Publishers GmbH 2009).

An International Approach to the Interpretation of the United Nations Convention on Contracts for the International Sale of Goods (1980) as Uniform Sales Law: A Comparative Approach (John Felemegas ed., Cambridge University Press, 1st ed. 2007).

Joubin-Bret, Anna, Reshaping the Investor-State Dispute Settlement System, Jean E Kalicki, -Infinity (Jean E. Kalicki and Anna Joubin-Bret eds., Brill Academic Publishers 2015).

Winer S. Anthony, the CISG Convention and Thomas Franck's Theory of Legitimacy, 19 Nw. J. Int'l L. \& Bus. 1 (1998-1999)

Leisinger, K Benjamin and B. Leisinger, Fundamental Breach Considering Non-Conformity of the Goods (BeitrageZumInternationalenWirtschaftsrecht/ Contributions on International Commercial Law) (sellier.European law publishers GmbH 2007).

Andersen,Camilla Baasch, Furthering the Uniform Application of the CISG: Sources of Law on the Internet, 10 Pace Int'l L. Rev. 403 (1998)Available at: http://digitalcommons.pace.edu/pilr/vol10/iss2/2

Chengwei, Cure by Non-Conforming Party: Perspectives from the CISG, UNIDROIT Principles, PECL and Case Law, section 3.3, available at http://www.cisg.law.pace.edu/cisg/biblio/chengwei1.html 
Permats, Christoffer, Seller's Right to Cure under the United Nations Convention for the International Sale of Goods (CISG), 2011, Page 29.

CLOUT case; CLOUT case No. 304 Arbitration-International Chamber of Commerce No. 7531, 1994. Available at: http://www.unilex.info/case.cfm?pid=1\&do=case\&id=139\&step=FullText

Commonwealth Secretariat, the United Nations Convention on Contracts for the International Sale of Goods (Legal \& Constitutional Affairs) (Commonwealth Secretariat 1991).

Current Issues in the CISG and Arbitration 27 (IngeborgSchwenzer et al. eds., Eleven International Publishing 2013).

Boote,David and BeilePenny, 'Scholars before Researchers: On the Centrality of the Dissertation Literature Review in Research Preparation' (2005) 36:6 Educational Researcher 3.

Thomas,David and HodgesIan, Doing a Literature Review in Designing and Managing your Research Project (Sage 2010) 105

DiMatteo, Larry A., and Daniel T. Ostas."Comparative Efficiency in International Sales Law." American University International Law Review 26 no. 2 (2011): 371-439.

Saidov,Djakhongirand Ralph Cunnington, Contract Damages: Domestic and International Perspectives (Ralph Cunnington and DjakhongirSaidov eds., Hart Publishing 2008).

Saidov,Djakhongir, The Law of Damages in the International Sale of Goods: The CISG and Other International Instruments (Intl Specialized Book Service 2008).

McKendrick,Ewan et al., Transnational Commercial Law: International Instruments and Commentary (Text Cases \& Materials) (Oxford University Press, USA, 1st ed. 2007).

Franco Ferrari, the CISG and Its Impact on National Legal Systems (Franco Ferrari ed., Sellier - European Law Publishers GmbH 2008).

Ferrari,Franco, CISG Case Law: A New Challenge for Interpreters?,Pace Institute of International Commercial Law, Journal of Law and Commerce (1999).

Moens,Gabriel: and Moens Gabriel, International Trade and Business Law Review: Volume XI (Gabriel Moens and Roger Jones eds., Routledge Cavendish, 1st ed. 2008).

Germany 21 April 2004 Appellate Court Düsseldorf [15 U 88/03] (Mobile car phones case), available at: http://cisgw3.law.pace.edu/cases/040421g3.html

Germany 24 April 1997 Appellate Court Düsseldorf (Shoes case), available at: http://cisgw3.law.pace.edu/cases/970424g1.html

Flechtner,Harry, Article 79 of the United Nations Convention on Contracts for the International Sale of Goods (CISG) as Rorschach Test: The Homeward Trend and Exemption for Delivering Non-Conforming Goods, 19 Pace Int'l L. Rev. 29 (2007) Available at: http://digitalcommons.pace.edu/pilr/vol19/iss1/3

Schwenzer,Ingeborgand Hachem Pascal, The CISG-Successes and Pitfalls, 57 American Journal of Comparative Law 457 (American Journal of Comparative Law 2009).

Schwenzer,Ingeborg H, Global Sales and Contract Law (Oxford University Press, USA 2012).

Honnold,John, Uniform Law For International Sales Under The 1980 United Nations Convention - Fourth Edition Revised (Sold and distributed in North, Central, and South America by Aspen Publishers, 4th ed. 2009).

Honnold,John, The Sales Convention in Action - Uniform International Words: Uniform Application? 8. 207208 (1988).

Honnold, John, Uniform Law for International Sales under the 1980 United Nations Convention, 3rd ed. 1999, § 184.

Spanogle,John, Global issues in contract law (Thomson/West) (2007)

Lookofsky,Joseph, Understanding the CISG in the USA: A Compact Guide to the 1980

Khandani,Kourosh, Does the CISG, Compared to English Law, Put Too Much Emphasis on Promoting Performance of the Contract despite a Breach by the Seller?, The University of Manchester (2012).

DiMatteo,Larry A., Commercial Contract Law: Transatlantic Perspectives (Larry DiMatteo ed., Cambridge University Press, 1st ed. 2013).

Spagnolo,Lisa, Cisg Exclusion and Legal Efficiency (Kluwer Law International 2014).

Davies Martin and David V Snyder, International Transactions in Goods : Global Sales in Comparative Context (Oxford University Press 2014).

McQuillen,Marlyse, The Development of a Federal CISG Common Law in U.S. Courts: Patterns of Interpretation and Citation, 61 U. Miami L. Rev. 509 (2007) Available at: http://repository.law.miami.edu/umlr/vol61/iss2/8

Maggi,Michael \&FraccioPatrice, Review of the Convention on Contracts for International Sale of Goods (CISG) (2005).

Rustad,Michael L, Understanding Sales, Leases, and Licenses in a Global Perspective (Carolina Academic Press 2008). 
O’NeillMaria, CONTRACTS FOR THE INTERNATIONAL SALE OF GOODS - THE SIGNIFICANCE OF 'FUNDAMENTAL BREACH' IN THE VIENNA CONVENTION, 1980., 2 Irish Business Law (1999).

Koblenz,Oberlandesgericht[Appellate Court], Germany, Acrylic Blankets Case, 31 January 1997.

Meyer,Olaf and Ebers, European Perspectives on Producers' Liability: Direct Producers' Liability for NonConformity and the Sellers' Right of Redress (Martin Ebers and Andr Janssen eds., Sellier - European Law Publishers GmbH 2009).

Gonzalez,Olga, Remedies under the U.N. Convention for the International Sale of Goods, 2 Int'l Tax \& Bus. Law.79 (1984). Available at: http://scholarship.law.berkeley.edu/bjil/vol2/iss1/4

Pace International Law Review (2007) Review of the Convention on Contracts for the International Sale of Goods (Cisg), 2005-2006. Edited by Pace International Law Review.United States: Sellier European Law Publishers.

Huber,Peter and Alastair Mullis, The CISG: A New Textbook for Students and Practitioners (Sellier - European Law Publishers GmbH 2007).

Schlechtriem,Peter, Subsequent Performance and Delivery Deadlines - Avoidance of CISG Sales Contracts due to Non-Conformity of the Goods, 18 Pace Int'l L. Rev. 83 (2006)

Available at: http://digitalcommons.pace.edu/pilr/vol18/iss 1/3

Schaffer et al. Richard,International Business Law and Its Environment (Thomson/South-Western, 6th ed. 2004).

Vogenauer,Stefan and KleinheisterkampJan, Commentary on the UNIDROIT Principles of International Commercial Contracts (PICC) (Stefan Vogenauer ed., Oxford University Press, USA, 1st ed. 2009)

Oser,David, The UNIDROIT Principles of International Commercial Contracts: A Governing Law? (MartinusNijhoff Publishers 2008).

Campbell,Dennis, Remedies for International Sellers of Goods - Volume II (Yorkhill Law Publ., 2d ed. 2006).

Delchi, Carrier SpA v. Roterex Corporation, 3 Delchi Carrier SpA v. Rotorex Corp

Saidov,Djakhongir, The Law of Damages in the International Sale of Goods: The CISG and Other International Instruments (Intl Specialized Book Service 2008).

Keilhack,Karsten, The Hardship Approach in the UNIDROIT Principles of International Commercial Contracts and Its Equivalent in German Law of Obligations - a Comparison (GRIN Verlag 2003).

Kluwer Law International (2000-2001), 9, at IV.C.3, also available online at <http://cisgw3.law.pace.edu/cisg/ biblio/williams.html>.

Malbon,Justin and Bernard Bishop, Australian Export: A Guide to Law and Practice (Cambridge University Press (Virtual Publishing) 2006).

Magnus, Ulrich. "CISG vs. CESL."With a Focus on the New Common European Sales Law CISG vs. Regional Sales Law Unification (2007). Print

Heidemann,Maren, Methodology of Uniform Contract Law: The UNIDROIT Principles in International Legal Doctrine and Practice (Springer-Verlag Berlin and Heidelberg GmbH \& Co. K, 1st ed. 2006).

Bridge,Michael, AVOIDANCE FOR FUNDAMENTAL BREACH OF CONTRACT UNDER THE UN CONVENTION ON THE INTERNATIONAL SALE OF GOODS, 59 International and Comparative Law Quarterly 911 (Cambridge University Press (CUP) 2010).

Netherlands, 7 October 2008, Gerechtshof[Appellate Court] Arnhem (ArensSondermaschinen GmbH v. SmitDraad / DraadNijmegent B.V.), available at: http://cisgw3.law.pace.edu/cases/081007n1.html

Neumann and Thomas Neumann, the Duty to Cooperate in International Sales: The Scope and Role of Article 80 Cisg (Sellier European Law Publishers 2012).

Koblenz,Oberlandesgericht[Appellate Court], Germany, Acrylic Blankets Case, 31 January 1997.

Lando et al.Ole, The Principles Of European Contract Law, Parts I And Ii (Kluwer Law International 2000).

The UNIDROIT Principles in Practice: Caselaw and Bibliography on the UNIDROIT Principles of International Commercial Contracts (Michael Bonell ed., Transnational Publishers Inc., U.S., 2d ed. 2006).

United Nations Commission and International Trade Law, United Nations Convention on Contracts for the International Sale of Goods (United Nations 2011).

United Nations Convention on Contracts for the International Sale of Goods (Kluwer Law International, $2 \mathrm{~d}$ ed. 2004).

United Nations Publications, UNCITRAL Digest of Case Law on the United Nations Convention on the International Sale of Goods (United Nations Pubns 2008).

Huber Peter and Alastair Mullis, the CISG: A New Textbook for Students and Practitioners (Sellier - European Law Publishers GmbH 2007).

Moens,Gabriel: and Moens Gabriel, International Trade and Business Law Review: Volume XI (Gabriel Moens and Roger Jones eds., Routledge Cavendish, 1st ed. 2008).

Michael,Furmston and Furmston, Sale \& Supply of Goods 3/e (Commercial Law) (Routledge Cavendish, 3d ed. 1999).

Peter Schlechtriem AND Petra Butler, UN Law on International Sales: The UN Convention on the 
International Sale of Goods (Springer-Lehrbuch) (Springer-Verlag Berlin and Heidelberg GmbH \& Co. K 2008).

Switzerland 5 November 2002 Commercial Court of the Canton of Aargau (Inflatable triumphal arch case), available at: http://cisgw3.law.pace.edu/cases/021105s 1.html

Italy 24 November 1989 Court of First Instance Parma (Foliopack v. Daniplast), available at: http://cisgw3.law.pace.edu/cases/891124i3.html

Williams, "Forecasting the Potential Impact of the Vienna Sales Convention on International Sales Law in the United Kingdom," Pace Review of the Convention on Contracts for the International Sale of Goods (Cisg), 